\title{
Oea
}

JURNAL PENDIDIKAN GEOGRAFI

\section{PENGARUH PEMBELAJARAN BERBASIS MASALAH TERHADAP SIKAP SISWA PADA LINGKUNGAN (Studi Eksperimen Quasi Pada Mata Pelajaran Geografi di SMA Negeri 1 Purwadadi)}

\author{
Dadang Djuandi \\ SMA Negeri 1 Purwadadi, Kab. Subang, email: dadjuaja@gmail.com
}

\begin{abstract}
ABSTRAK
Earth hour, kantong plastic berbayar, dan penanaman sejuta pohon adalah wujud meningkatnya kepedulian manusia pada lingkungan yang semestinya diikuti pula dengan makin baiknya sikap siswa pada lingkungan, tetatpi sikap siswa pada lingkungan masih bersifat negative. Penelitian ini bertujuan untuk menganalisis pengaruh penggunaan model pembelajaran berbasis masalah (PBM) terhadap sikap siswa pada lingkungan. Model pembelajaran tersebut diterapkan karena sesuai dengan prinsip pembelajaran yang berpusat pada permasalahan yang terjadi nyata dekat dengan siswa. Data diperoleh menggunakan metode penelitian quasi eksperimen, dengan pengujian sikap pada pretest dan posttest, Teknik pengolahan data penelitian menerapkan uji $t$. Untuk menguji hipotesis peneliti menerapkan perhitungan statistik dengan memanfaatkan software SPSS versi 21 . Subjek penelitian ini adalah siswa kelas XI IPS 2 dan kelas XI IPS 4. Hasil peneltian menunjukkan: (1) sesudah penerapan PBM sikap siswa di kelas eksperimen mengalami peningkatan; (2) sesudah pembelajaran konvensional sikap siswa pada lingkungan di kelas kontrol mengalami peningkatan; (3) sikap siswa pada lingkungan kelas eksperimen lebih baik daripada kelas kontrol; (4) di kelas eksperimen sikap siswa kelompok atas pada lingkungan lebih baik daripada kelompok bawah. Untuk meningkatkan keaktifan siswa perlu penerapan PBM lebih intensif, dan penelitian ini sebaiknya ditindaklanjuti dengan penelitian pada prilaku.
\end{abstract}

Kata kunci: model pembelajaran, pembelajaran berbasis masalah, sikap.

\section{PENDAHULUAN}

Kepedulian pada lingkungan harus sudah menjadi bagian dari kehidupan kita.Kepedulian ini nampaknya makin marak disuarakan, dipublikasikan bahkan dikampanyekan, seperti misalnya bisa disebutkan seperti "Jam Bumi" atau earth hour yang digagas oleh WWF sejak tahun 2008. Jam bumi merupakan wujud kepedulian pada lingkungan dengan aktivitas berupa pemadaman listrik selama satu jam. Menurut ketua MPR, Wahyudin "Meskipun hanya satu jam, tapi kita sudah mencontohkan masyarakat tentang pelestarian lingkungan hidup dan kepedulian terhadap penurunan emisi karbon yang memicu pemanasan global." (http://www.antaranews.com, 2016).
Gerakan sejuta pohon sedunia yang diperingati setiap tanggal 10 Januari adalah bentuk kepedulian yang juga sangat penting bagi pelestarian lingkungan. Gerakan penanaman pohon ini dilakukan karena pohon diketahui dapat mengurangi kadar CO2 di udara dan menghasilkan O2. Pohon juga dapat menahan laju air sehingga akan lebih banyak yang terserap ke dalam tanah. Menurut penelitian national geographic bahwa tegakan hutan yang berdaun jarum mampu membuat 60 persen air hujan terserap tanah.Tegakan hutan yang berdaun lebar mampu membuat 80 persen air hujan terserap tanah (http://madina.go.id, 2013). Hal lain yang menunjukkan kepedulian pada lingkungan adalah upaya mengurangi pencemaran 
udara melalui pengurangan jumlah kendaran yang berusia lebih dari sepuluh tahun. Misalnya pemerintah DKI dengan program scrapping mobil yang pernah dilontarkan oleh Gubernur Ahok (http://megapolitan.kompas.com, 2015), Scrapping yaitu tempat penghancuran mobil-mobil berusia di atas 10 tahun, atau penerapan pajak progresif seperti yang diungkapkan oleh Ketua Masyarakat Transportasi Indonesia (MTI) bahwa "pemerintah DKI Jakarta perlu memberlakukan pengenaan pajak progresif bagi kendaraan pribadi yang telah berusia di atas 10 tahun. Dengan penerapan pajak progresif ini semakin tua kendaraan semakin mahal pajak yang harus dibayarkan oleh pemilik.Hal ini dilakukan dengan orientasi untuk mengurangi polusi. (Kompas.com, 2015).

Kebersihan sebagian dari iman atau Jagalah kebersihan dan Buanglah sampah ke tempatnya merupakan kata-kata atau pernyataan yang berisi ajakan untuk selalu membiasakan diri berprilaku hidup bersih di manapun berada.Kata-kata ajakan tersebut sudah menjadi kata-kata yang populer di kalangan para peserta didik maupun masyarakat pada umumnya.Tidak hanya tertulis di dinding, atau di papan kayu Kata-kata ajakan bahkan tertulis pula di kemasan-kemasan produk makanan/ minuman.Tidak hanya berupa ajakan bersifat persuasif, bahkan ajakan bersifat represif pun terpampang di pinggir jalan, seperti di Kota Bandung, "Membuang sampah sembarangan didenda Rp. 5.000.000". Ajakan-ajakan tersebut menunjukkan bahwa sikap dan prilaku masyarakat terhadap lingkungan masih bersifat negatif atau kurang peduli. Berdasarkan pengamatan penulis, sikap dan prilaku negatif tersebut juga terjadi di lingkungan sekolah seperti di SMA Negeri 1 Purwadadi Subang.Kata-kata ajakan itu sudah mereka pahami maksudnya, dan melekat kuat pada memorinya akan tetapi mereka tidak mampu menjaga kebersihan kelasnya padahal tempat sampah tersedia di depan setiap kelas. Sampah akan beserakan di bawah meja dan kursi atau di bagian belakang ruang kelas terutama terjadi setelah waktu istirahat, dan ini berlangsung setiap hari sekolah. Sehingga menjadi pemandangan yang tidak sedap dilihat dan kurang nyaman untuk kegiatan belajar mengajar. Himbauan dan ajakan mulai dari yang halus sampai yang keras hanya dapat diikuti sesaat. Hukuman dan pengahargaan yang diberikan pun tidak mampu membuat prilaku siswa secara kontinyu menjaga kebersihan kelasnya.

Manusia dengan lingkungan tidak dapat dipisahkan, keduanya saling mempengaruhi. Hidup dan prilaku manusia pun dipengaruhi oleh lingkungan, prilaku manusia mempengaruhi lingkungan. Bahkan dapat dikatakan bahwa manusia itu tergantung pada lingkungannya. "seharusnya manusia menghormati lingkungan hidup guna keberlangsungan hidup manusia itu sendiri. Karena itu, manusia seharusnya mampu menanamkan rasa tanggung jawab terhadap lingkungan agar kelestarian alam tetap terjaga." (Martanti, 2009, hal. 17).

Pendidikan merupakan wahana yang sangat efektif untuk menumbuhkan dan mewujudkan harmonisasi antara manusia dengan lingkungannya. Saat ini permasalahan lingkungan merupakan permasalahan yang mendesak untuk segera diatasi (Muhaimin, 2014, hal. 14). Bagaimana agar kemampuan mengatasi masalah lingkungan ini dimiliki oleh siswa? Apakah kemampuan ini dapat ditumbuhkembangkan melalui pembelajaran? Proses pembelajaran pada hakekatnya merupakan proses komunikasi, yaitu proses penyampaian pesan atau informasi dari guru kepada peserta didik. Oleh karena itu maka agar siswa memiliki kemampuan memecahkan masalah lingkungan perlu diperhatikan strategi penyampaiannya. Dengan demikian guru harus mampu memilih model pembelajaran yang mampu mendorong semangat siswa untuk secara aktif terlibat dalam 
pengalaman belajarnya. Siswa harus aktif sebagai "Pemecah Masalah"bukan aktif sebagai pembuat masalah. Menurut Yani (2014, hal. 136) Problem Based Learning (PBL) atau Pembelajaran Berbasis Masalah (PBM) merupakan model pembelajaran yang memungkinkan bagi peserta didik untuk aktif dan berani mengajukan solusi dari masalah yang sedang dihadapi.

Tujuaan penelitian ini adalah: 1) Untuk menganalisis bagaimana pengaruh penggunaan model pembelajaran berbasis masalah (PBM) terhadap sikap siswa pada lingkungan 2) Untuk menganalisis bagaimana pengaruh penggunaan model pembelajaran yang tidak menggunakan PBM terhadap sikap siswa pada lingkungan 3) Untuk menganalisis adakah perbedaan sikap siswa pada lingkungan antara kelas eksperimen dengan kelas kontrol. 4) Untuk menganalisis adakah perbedaan sikap siswa pada lingkungan antara kelompok atas (pandai) dengan kelompok bawah (kurang) pada kelas eksperimen.

\section{METODE PENELITIAN}

Metode penelitian yang digunakan adalah metode eksperimen untuk menguji hubungan sebab akibat penerapan model PBM terhadap sikap siswa pada lingkungan, kemudian hasilnya dibandingkan dengan kelompok kontrol. Metode pengumpulan data yang digunakan adalah tes skala sikap Likert, dan observasi. Tes skala sikap diuji validitas dan reliabilitasnya. Data yang terkumpul kemudian diolah dengan uji homogenitas, uji normalitas, persentase, peningkatan (gain), dan uji-t.

\section{HASIL DAN PEMBAHASAN}

Hasil pengolahan data statistik kelas eksperimen dapat dilihat pada tabel 1 . Berdasarkan tabel 1, skor sikap pada kelas eksperimen saat sebelum diberi perlakuan memperoleh skor rata-rata sebesar 125,64, skor maksimum 145,00, dan skor minimum 88. Setelah memperoleh perlakuan dengan
Pembelajaran

Berbasis

Masalah memperoleh skor rata-rata sebesar 134,5 skor maksimum 149, dan skor minimum 109. Berdasarkan hasil perhitungan tersebut maka setelah diberi perlakuan kelas eksperimen memperoleh kenaikan skor rata-rata sebesar 8,86.Kenaikan tinggi pada kelas eksperimen terjadi pada skor minimum yang memperoleh kenaikan skor sebesar 21.

Tabel 1. Data statistik pretest dan posttest kelas eksperimen

\begin{tabular}{cccc}
\hline $\begin{array}{c}\text { Data } \\
\text { Statistik }\end{array}$ & Pretest & Posttest & Perubahan \\
\hline Rata-rata & 125.64 & 134.50 & 8,86 \\
\hline Skor maks & 145 & 149 & 4 \\
\hline skor min & 88 & 109 & 21 \\
\hline
\end{tabular}

Kategori gain sikap yang diperoleh kelas eksperimen dapat dilihat pada tabel 2.

Tabel 2.Kategori Nilai Gain Kelas Eksperimen

\begin{tabular}{|c|c|c|c|}
\hline Nilai Gain & Kategori & $\mathrm{F}$ & $\%$ \\
\hline$<0,3$ & Rendah & 15 & 42 \\
\hline $0,3 \leq \mathrm{g}<0,7$ & Sedang & 21 & 58 \\
\hline$\geq 0,7$ & Tinggi & 0 & 0 \\
\hline \multicolumn{2}{|c|}{ Jumlah } & 36 & 100 \\
\hline
\end{tabular}

Dari tabel 2 dapat dijelaskan bahwa peningkatan nilai gain terjadi pada seluruh siswa (100\%) yang terbagi pada kategori rendah dan sedang, tetapi tidak terjadi peningkatan pada kategori tinggi. Peningkatan pada kategori rendah dicapai oleh 15 orang atau sekitar $42 \%$.Peningkatan pada kategori sedang dicapai oleh 21 orang atau sekitar 58\%. Rata-rata peningkatan sikap pada kelas eksperimen adalah sebesar 0,3 termasuk ke dalam kategori sedang.

Untuk keperluan pengujian hipotesis, maka ketentuan terhadap diterimanya hipotesis ditunjukkan oleh nilai sig. (2tailed). Ketentuannya adalah jika nilai sig. $>0,05$, maka $\mathrm{H}_{0}$ diterima, sebaliknya jika nilai sig. < 0,05 maka $\mathrm{H}_{0}$ ditolak (Gunawan, 2013, hlm. 118). Hasil pengujian kelas eksperimendapat dilihat pada tabel 3. 
Tabel 3. Hasil Uji Paired Samples Test (uji-t) Kelas Eksperimen

\begin{tabular}{|c|c|c|c|c|c|c|c|c|c|}
\hline & & \multicolumn{5}{|c|}{ Paired Differences } & \multirow[t]{3}{*}{$t$} & \multirow[t]{3}{*}{$\mathrm{df}$} & \multirow{3}{*}{$\begin{array}{l}\text { Sig. (2- } \\
\text { tailed) }\end{array}$} \\
\hline & & \multirow[t]{2}{*}{ Mean } & \multirow[t]{2}{*}{$\begin{array}{c}\text { Std. } \\
\text { Deviation }\end{array}$} & \multirow{2}{*}{$\begin{array}{l}\text { Std. } \\
\text { Error } \\
\text { Mean }\end{array}$} & \multicolumn{2}{|c|}{$\begin{array}{l}95 \% \text { Confidence Interval } \\
\text { of the Difference }\end{array}$} & & & \\
\hline & & & & & Lower & Upper & & & \\
\hline Pair 1 & $\begin{array}{l}\text { Pre_Post_ } \\
\text { Eks - } \\
\text { Kelas }\end{array}$ & 128,56944 & 12,26334 & 1,44525 & 125,68770 & 131,45119 & 88,960 & 71 & ,000 \\
\hline
\end{tabular}

Dari tabel 3 tersebut dapat diketahui bahwa nilai $\mathrm{t}$ adalah 88,960 , dan derajat kebebasan 71, serta nilai sig. (2-tailed) yang diperoleh adalah 0,000. Dengan demikian nilai sig. yang diperoleh $<0,05$ sehingga dapat disimpulkan $\mathrm{H}_{0}$ ditolak dan menerima $\mathrm{H}_{1}$. Berdasarkan pengujian tersebut dapat disimpulkan: ada perbedaan sikap siswa pada lingkungan di kelas eksperimen sebelum dan sesudah perlakuan.

Setelah perlakuan dengan menggunakan model PBM kelas eksperimen secara signifikan mengalami peningkatan sikap yang lebih baik. Pembelajaran Berbasis Masalah yang diterapkan pada kelas eksperimen berpengaruh terhadap perkembangan sikap siswa. Artinya sikap siswa di kelas eksperimen meningkat secara signifikan setelah memperoleh pembelajaran dengan model PBM. Peningkatan nilai gain meliputi semua siswa dengan rata-rata peningkatan gain sebesar 0,3 yang tergolong kategori sedang. Pembelajaran yang dilaksanakan di kelas eksperimen yang menggunakan model Pembelajaran Berbasis Masalah (Problem Based Learning) telah berhasil membawa perubahan sikap siswa pada lingkungan menjadi lebih baik atau lebih positif. Pernyataan ini didukung oleh Shoimin (2014, hal. 20) bahwa, "Oleh karenanya diperlukan strategi bagaimana pendidikan bisa menjadi sarana untuk membuka pola pikir peserta didik bahwa ilmu yang mereka pelajari memilki kebermaknaan untuk hidup sehingga ilmu tersebut mampu mengubah sikap, pengetahuan, dan keterampilan menjadi lebih baik". Demikian pula Asna Khuroidah, dkk (2013) melakukan penelitian tentang "Peningkatan Kemampuan Memecahkan Masalah Dan Hasil Belajar
Geografi Melalui Model Pembelajaran Problem Based Learning". Hasil penelitiannya bahwa penerapan pembelajaran model Problem Based Learning dapat meningkatkan kemampuan memecahkan masalah dan hasil belajar.

Hasil temuan di kelas kontrol secara statistik dapat diketahui dari tabel 4 .

Tabel 4. Data statistik pretest dan posttest kelas kontrol

\begin{tabular}{lccc}
\hline Data Statistik & Pretest & Posttest & Perubahan \\
\hline Rata-rata & 125,39 & 130,58 & 5,19 \\
\hline Skor maks & 145 & 147 & 2 \\
\hline skor min & 84 & 90 & 6 \\
\hline
\end{tabular}

Dari tabel 4 dapat diketahui bahwa ratarata hasil pretest dan posttest kelas kontrol masing-masing adalah 125,39 dan 130,58, berarti mengalami kenaikan skor sebesar 5,19 . Skor maksimum yang diperoleh hasil pretest dan posttest kelas kontrol masingmasing adalah sebesar 145 dan 147, berarti mengalami kenaikan skor sebesar 2. Skor minimum yang diperoleh hasil pretest dan posttest kelas kontrol masing-masing adalah sebesar 84 dan 90, berarti mengalami kenaikan skor sebesar 6. Dari keseluruhan hasil tes pada kelas kontrol ternyata peningkatan pada skor minimum adalah yang paling tinggi.

Kategori gain sikap yang diperoleh kelas eksperimen dapat dilihat pada tabel 5.

Tabel 5. Kategori Nilai Gain Kelas Kontrol

\begin{tabular}{cccc}
\hline Nilai Gain & Kategori & F & $\%$ \\
\hline$<0,3$ & Rendah & 30 & 83 \\
\hline $0,3 \leq \mathrm{g}<0,7$ & Sedang & 6 & 17 \\
\hline$\geq 0,7$ & Tinggi & 0 & 0 \\
\hline Jumlah & & 36 & 100 \\
\hline
\end{tabular}


Dari tabel 5 dapat diketahui bahwa setiap siswa pada kelas kontrol mengalami peningkatan. Peningkatan tersebut meliputi kategori rendah dan sedang tetapi tidak terjadi peningkatan pada kategori tinggi.Peningkatan pada kategori rendah mencapai 30 orang atau $83 \%$, peningkatan pada kategori sedang mencapai 6 orang atau 17\%.Hal ini menunjukkan bahwa pembelajaran di kelas kontrol juga meningkatkan sikap siswa pada lingkungan menjadi lebih baik.

Untuk keperluan pengujian hipotesis, maka ketentuan terhadap diterimanya hipotesis ditunjukkan oleh nilai sig. (2tailed). Ketentuannya adalah jika nilai sig. $>0,05$, maka $\mathrm{H}_{0}$ diterima, sebaliknya jika nilai sig. $<0,05$ maka $\mathrm{H}_{0}$ ditolak (Gunawan, 2013, hlm. 118). Hasil pengujian kelas eksperimendapat dilihat pada tabel 6 .

Tabel 6. Hasil Uji t Kelas Kontrol

Paired Samples Test

\begin{tabular}{|c|c|c|c|c|c|c|c|c|c|}
\hline & & \multicolumn{5}{|c|}{ Paired Differences } & \multirow[t]{3}{*}{$\mathrm{t}$} & \multirow[t]{3}{*}{$\mathrm{df}$} & \multirow{3}{*}{$\begin{array}{l}\text { Sig. (2- } \\
\text { tailed) }\end{array}$} \\
\hline & & \multirow[t]{2}{*}{ Mean } & \multirow[t]{2}{*}{$\begin{array}{c}\text { Std. } \\
\text { Deviation }\end{array}$} & \multirow[t]{2}{*}{$\begin{array}{l}\text { Std. } \\
\text { Error } \\
\text { Mean }\end{array}$} & \multicolumn{2}{|c|}{$\begin{array}{c}95 \% \text { Confidence } \\
\text { Interval of the } \\
\text { Difference } \\
\end{array}$} & & & \\
\hline & & & & & Lower & Upper & & & \\
\hline Pair 1 & $\begin{array}{l}\text { Pre_Pos } \\
\text { t_Kontr } \\
\text { ol - } \\
\text { Kelas }\end{array}$ & 126,48611 & 11,09751 & 1,30785 & 123,87832 & 129,09390 & 96,713 & 71 & ,000 \\
\hline
\end{tabular}

Dari tabel 6 dapat diketahui bahwa kelas kontrol memiliki nilai rata-rata 126, 49, nilai $t$ adalah 96,713, dan derajat kebebasan sebesar 71, serta nilai sig (2tailed) 0,000. Berdasarkan ketentuan di atas yaitu apabila nilai sig (2-tailed) < dari 0,05 maka $\mathrm{H}_{0}$ ditolak dan menerima $\mathrm{H}_{1}$. Berdasarkan pengujian tersebut maka dapat disimpulkan: ada perbedaan sikap siswa pada lingkungan di kelas kontrol sebelum dan sesudah perlakuan.

Berdasarkan pengujian tersebut maka dapat disimpulkan: ada perbedaan sikap siswa pada lingkungan di kelas kontrol sebelum (pre test) dan sesudah (post test). Hal ini berarti bahwa di kelas kontrol pun setelah pembelajaran mengalami peningkatan sikap menjadi lebih baik. Pembelajaran di kelas kontrol berpengaruh terhadap perkembangan sikap siswa. Artinya sikap siswa di kelas kontrol meningkat secara signifikan.Peningkatan nilai gain meliputi semua siswa dengan rata-rata peningkatan gain sebesar 0,2 yang tergolong kategori rendah. Pembelajaran yang dilaksanakan di kelas kontrol telah berhasil membawa perubahan sikap menjadi lebih baik. Hasil penelitian ini sesuai dengan pendapat Sudjana (1989:56) pendidikan dan pengajaran dikatakan berhasil apabila perubahan-perubahan yang tampak pada siswa harus merupakan akibat dari proses belajar mengajar yang dialaminya. Sehingga proses pembelajaran berpengaruh terhadap perubahan diri siswa, salah satunya adalah pada sikap. Perubahan sikap yang lebih baik ini juga sejalan dengan hasil penelitian Novia Kresnawati (2013) bahwa "ada korelasi positif yang signifikan antara kualitas pembelajaran Geografi dengan sikap peduli lingkungan".

\section{Perbedaan antara kelas eksperimen dan kelas kontrol}

Perbandingan prosentase sikap siswa pada lingkungan antara kelas eksperimen dan kelas kontrol dapat dilihat pada tabel 7. Berdasarkan tabel 7 dapat diketahui bahwa sikap siswa baik di kelas eksperimen maupun di kelas kontrol keduanya mengalami peningkatan yang makin positif 
artinya mengalami peningkatan sikap ke arah yang lebih baik. Hal ini dapat dibuktikan dari keduanya sama-sama mengalami peningkatan persentase pada kriteria penilaian baik. Walau keduanya mengalami peningkatan lebih baik, kelas eksperimen mengalami peningkatan lebih besar daripada peningkatan yang diperoleh kelas kontrol. Kelas eksperimen meningkat $17 \%$ sedangkan kelas kontrol meningkat 13 $\%$. Kelas eksperimen dan kelas kontrol pada kriteria cukup mengalami penurunan yang sama, yaitu 11\%. Pada kriteria kurang kelas eksperimen mengalami penurunan sebesar $6 \%$ sedangkan pada kelas kontrol hanya menurun $2 \%$. Berdasarkan data tersebut, hal ini menunjukkan bahwa pembelajaran di kelas eksperimen yang menggunakan pembelajaran berbasis masalah lebih baik daripada yang menggunakan pembelajaran konvensional.

Peningkatan atau data gain sikap kelas eksperimen dan kelas kontrol dapat dilihat dari tabel 8.

Tabel 7. Kriteria penilaian sikap kelas eksperimen dan kelas kontrol

\begin{tabular}{ccccccc}
\hline \multirow{2}{*}{ Hasil } & \multirow{2}{*}{ Hasil Skor } & Kriteria & \multicolumn{2}{c}{ K. Eksp } & \multicolumn{2}{c}{ K. Kontr } \\
\cline { 4 - 6 } Persentase & & Penilaian & \multirow{2}{*}{ Pretest } & Posttest & \multirow{2}{*}{ Pretest } & \multirow{2}{*}{ Posttest } \\
\hline $76 \%-100 \%$ & $121-160$ & Baik & $75 \%$ & $92 \%$ & $81 \%$ & $94 \%$ \\
\hline $56 \%-75 \%$ & $90-120$ & Cukup & $19 \%$ & $8 \%$ & $17 \%$ & $6 \%$ \\
\hline$<56 \%$ & $<90$ & Kurang & $6 \%$ & $0 \%$ & $2 \%$ & $0 \%$ \\
\hline & Jumlah & & $100 \%$ & $100 \%$ & $100 \%$ & $100 \%$ \\
\hline
\end{tabular}

Tabel 8. Data gain sikap kelas eksperimen dan kelas kontrol

\begin{tabular}{cccccc}
\hline Nilai Gain & Kategori & $\mathbf{F}$ & $\mathbf{0}$ & $\mathbf{F}$ & $\mathbf{\%}$ \\
\hline$<0,3$ & Rendah & 15 & 42 & 30 & 83 \\
\hline $0,3 \leq \mathrm{g}<0,7$ & Sedang & 21 & 58 & 6 & 17 \\
\hline$\geq 0,7$ & Tinggi & 0 & 0 & 0 & 0 \\
\hline \multicolumn{2}{c}{ Jumlah } & 36 & 100 & 36 & 100 \\
\hline
\end{tabular}

Dari tabel 8 dapat diketahui bahwa baik pada kelas eksperimen maupun pada kelas kontrol tidak ada peningkatan (gain) sikap pada kategori tinggi. Keduanya hanya ada peningkatan pada gain berkategori rendah $(<0,3)$ dan gain berkategori sedang $(0,3 \leq \mathrm{g}<$ $0,7)$.Berdasarkan perhitungan statistic kedua kelas ini dapat dilihat pada tabel 9.

Berdasarkan tabel 9 dapat diketahui bahwa kelas eksperimen memperoleh nilai rata-rata sebesar 134,5 sedangkan kelas kontrol nilai rata-ratanya adalah 129,5833 dengan demikian nilai rata-rata yang diperoleh kelas eksperimen lebih besar daripada kelas kontrol.

Signifikansi nilai rata-rata yang diperoleh kedua kelas dapat diketahui berdasarkan hasil uji t pada tabel 10 .

Tabel 9. Hasil Perhitungan Kelas Eksperimen dan kelas Kontrol Group Statistics

\begin{tabular}{lccccc}
\hline & Kelas & $\mathrm{N}$ & Mean & Std. Deviation & Std. Error Mean \\
\hline Post_Eks & Eksperimen & 36 & 134,5000 & 10,40467 & 1,73411 \\
_Kontrol & Kontrol & 36 & 129,5833 & 10,13727 & 1,68955 \\
\hline
\end{tabular}

Berdasarkan tabel 10 diketahui bahwa nilai t-test yang diperoleh adalah 2,031, dan nilai sig (2-tailed) 0,046. Berdasarkan ketentuan yaitu apabila nilai sig (2-tailed) < dari 0,05 maka $\mathrm{H}_{0}$ ditolak dan menerima $\mathrm{H}_{1}$. Berdasarkan pengujian tersebut maka dapat disimpulkan: ada perbedaan sikap siswa pada lingkungan antara kelas eksperimen dan kelas kontrol.

Berdasarkan pengujian tersebut maka dapat disimpulkan: ada perbedaan sikap siswa pada lingkungan antara kelas eksperimen dan kelas kontrol. Hal ini berarti pembelajaran yang menggunakan 
model Pembelajaran Berbasis Masalah memberikan perubahan sikap yang lebih baik daripada pembelajaran di kelas kontrol. Hasil penelitian ini sejalan dengan hasil penelitian Didik Juliawan (2012) mengenai "Pengaruh Model Pembelajaran Berbasis Masalah Terhadap Pemahaman Konsep dan Keterampilan Proses Sains Siswa Kelas XI IPA SMA Negeri 2 Kuta Tahun Pelajaran 2011/2012", yaitu bahwa, "terdapat perbedaan pemahaman konsep yang signifikan antara siswa yang mengikuti model pembelajaran berbasis masalah dan konvensional. Rata-rata pemahaman konsep siswa yang menggunakan model pembelajaran berbasis masalah lebih besar daripada yang menggunakan model pembelajaran konvensional". Penerapan model Pembelajaran Berbasis Masalah mampu memberikan peningkatan sikap lebih baik secara signifikan daripada Pembelajaran dengan model konvensional. Hal ini dapat dijelaskan oleh adanya manfaat dari pembelajaran berbasis masalah seperti yang dikemukakan oleh Amir (2014, hlm. 28): 1) Menjadi lebih ingat dan meningkatnya pemahaman atas materi ajar; 2) Meningkatkan fokus pada pengetahuan yang relevan; 3) Mendorong untuk berfikir; 4) Membangun kerja tim, kepemimpinan dan keterampilan social; 5) Membangun kecakapan belajar (life long learning skill); 6) Memotivasi pemelajar.

Tabel 10. Hasil Uji t Kelas Eksperimen dan kelas Kontrol Independent Samples Test

\begin{tabular}{|c|c|c|c|c|c|c|c|c|c|c|}
\hline & & \multicolumn{2}{|c|}{$\begin{array}{l}\text { Levene's } \\
\text { Test for } \\
\text { Equality of } \\
\text { Variances }\end{array}$} & \multicolumn{7}{|c|}{ t-test for Equality of Means } \\
\hline & & \multirow[t]{2}{*}{$\mathrm{F}$} & \multirow[t]{2}{*}{ Sig. } & \multirow[t]{2}{*}{$\mathrm{t}$} & \multirow[t]{2}{*}{ df } & \multirow[t]{2}{*}{$\begin{array}{l}\text { Sig. (2- } \\
\text { tailed) }\end{array}$} & \multirow[t]{2}{*}{$\begin{array}{c}\text { Mean } \\
\text { Difference }\end{array}$} & \multirow[t]{2}{*}{$\begin{array}{l}\text { Std. Error } \\
\text { Difference }\end{array}$} & \multicolumn{2}{|c|}{$\begin{array}{l}95 \% \text { Confidence } \\
\text { Interval of the } \\
\text { Difference }\end{array}$} \\
\hline & & & & & & & & & Lower & Upper \\
\hline \multirow{2}{*}{$\begin{array}{l}\text { Post_Eks_ } \\
\text { Kontrol }\end{array}$} & $\begin{array}{l}\text { Equal } \\
\text { varia } \\
\text { nces } \\
\text { assu } \\
\text { med }\end{array}$ & 907 & 344 & 2,031 & 70 & , 046 & 4,91667 & 2,42110 & 08794 & 9,74539 \\
\hline & $\begin{array}{l}\text { Equal } \\
\text { varia } \\
\text { nces } \\
\text { not } \\
\text { assu } \\
\text { med }\end{array}$ & & & 2,031 & 69,953 & , 046 & 4,91667 & 2,42110 & 08789 & 9,74545 \\
\hline
\end{tabular}

Perbedaan kelompok pandai dan kelompok kurang pada kelas eksperimen

Sikap siswa kelas eksperimen yang dikelompokkan berdasarkan tingkat kemampuannya menjadi kelompok atas, menengah, dan bawah dapat dilihat pada tabel 11. Dari tabel 11 dapat diketahui bahwa semua kelas baik kelas atas, menengah maupun bawah semuanya mengalami peningkatan sikap. Kelas sedang, dan kelas bawah sama-sama meningkat pada kategori gainrendah $(\mathrm{g}<$ $0,3)$ sedangkan kelas atas meningkat semuanya pada kategori gain sedang $(0,3 \leq$ $\mathrm{g}<0,7$ ). Tidak ada peningkatan (gain) kelompok kelas pada kategori tinggi.

Hasil uji $t$ terhadap kelompok menurut kemampuannya di kelas eksperimen dapat dilihat pada tabel 12 . Berdasarkan tabel 12, diketahui bahwa nilai t yang diperoleh adalah -13,161, derajat kebebasannya adalah 35 , dan nilai sig (2tailed) adalah 0,000. Berdasarkan ketentuan, yaitu apabila nilai sig (2-tailed) $<$ dari 0,05 maka $\mathrm{H}_{0}$ ditolak dan menerima $\mathrm{H}_{1}$. Berdasarkan pengujian tersebut maka dapat disimpulkan: ada perbedaan sikap siswa pada lingkungan antara kelompok 
atas dan kelompok bawah pada kelas eksperimen. Kesimpulan tersebut menunjukkan bahwa kelompok atas memiliki rata- rata sikap peduli pada lingkungan yang lebih baik daripada kelompok kelas menengah maupun bawah.

Tabel 11. Kategori Gain Kelas Eksperimen Menurut Kemampuan

\begin{tabular}{|c|c|c|c|c|c|c|c|}
\hline \multirow{2}{*}{ Nilai Gain } & \multirow{2}{*}{ Kategori } & \multicolumn{2}{|c|}{ Kelas Atas } & \multicolumn{2}{c|}{ Kelas Sedang } & \multicolumn{2}{c|}{ Kelas Bawah } \\
\cline { 3 - 8 } & & $\mathrm{F}$ & $\%$ & $\mathrm{~F}$ & $\%$ & $\mathrm{~F}$ & $\%$ \\
\hline$<0,3$ & Rendah & 0 & 0 & 9 & 100 & 18 & 100 \\
\hline $0,3 \leq \mathrm{g}<0,7$ & Sedang & 9 & 100 & 0 & 0 & 0 & 0 \\
\hline$\geq 0,7$ & Tinggi & 0 & 0 & 0 & 0 & 0 & 0 \\
\hline \multicolumn{2}{|c|}{ Jumlah } & 9 & 100 & 9 & 100 & 18 & 100 \\
\hline
\end{tabular}

Tabel 12. Hasil uji t kelompok siswa dalam kelas eksperimen Paired Samples Test

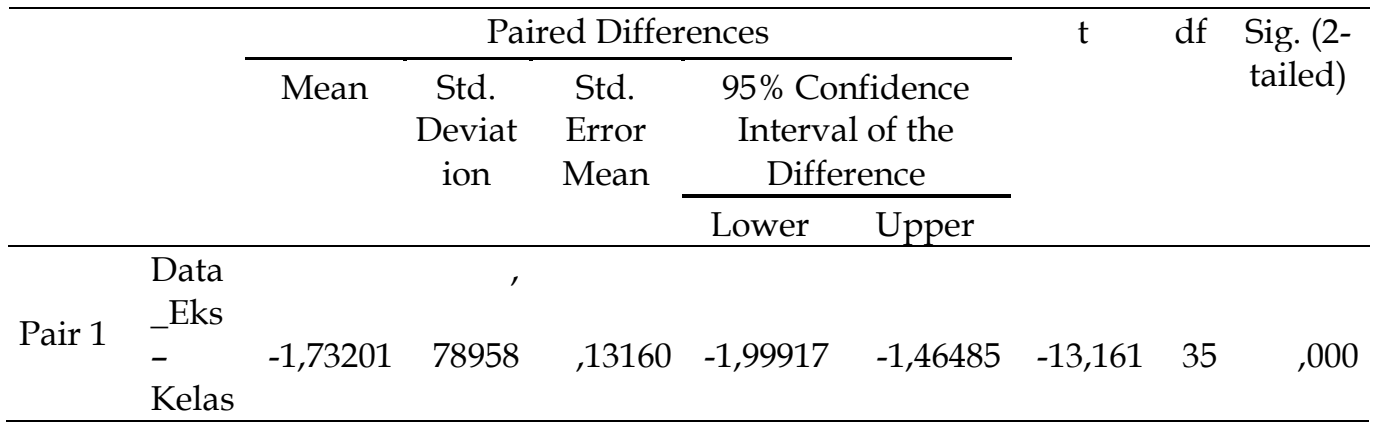

Kesimpulan tersebut sejalan dengan pendapat Wantania (tanpa tahun) dalam penelitiannya tentang "Hubungan antara Pendidikan Lingkungan dengan Sikap Siswa SLTP terhadap Pelestarian Lingkungan (Survei tentang Pendidikan Lingkungan pada siswa SLTP di Jakarta)" menemukan bahwa ada hubungan yang cukup bermakna antara tingkat pengetahuan materi pendidikan lingkungan hidup dengan sikap siswa terhadap pelestarian lingkungan. Demikian pula dengan hasil penelitian yang dilakukan oleh Muryanto (2012) tentang "Hubungan Pendidikan Lingkungan dan Sikap Siswa Terhadap Upaya Pelestarian Lingkungan di SMP Getasan Kabupaten Semarang" menemukan bahwa ada hubungan positif antara pengetahuan siswa tentang lingkungan dengan Upaya Pelestarian lingkungan hidup". Dari kedua peneliti tersebut dapat disimpulkan bahwa pengetahuan yang dimiliki siswa mempengaruhi sikap siswa artinya makin tinggi pengetahuan siswa tentang lingkungan maka sikap siswa juga akan lebih baik terhadap lingkungan. Hasil penelitian Semara Putera, Ida. Bagus Nyoman (2012) yaitu bahwa:

Siswa yang memiliki IQ tinggi, hasil belajar Biologi dengan model pembelajaran problem based learning lebih tinggi daripada siswa yang belajar dengan model pembelajaran langsung.Siswa yang memiliki IQ rendah, hasil belajar Biologi dengan model pembelajaran langsung lebih tinggi daripada siswa yang belajar dengan model pembelajaran problem based learning".

Model pembelajaran PBL berdasarkan penelitian Semara Putera tersebut mengindikasikan bahwa model $P B L$ cocok diterapkan pada siswa yang memiliki IQ tinggi. Sedangkan pembelajaran langsung cocok diterapkan di kelas yang memiliki IQ rendah.

\section{Kendala pelaksanaan PBM}

Pelaksanaan pembelajaran dengan menggunakan model PBM menunjukkan 
adanya peningkatan sikap yang signifikan. PBM ini masih mengalami beberapa Walaupun demikian pada pelaksanaannya kendala, seperti terlihat pada tabel 13.

Tabel 13.Tabel hasil observasi pelaksanaan PBM

\begin{tabular}{|c|c|c|c|c|c|c|c|c|}
\hline \multirow[t]{2}{*}{ No } & \multirow[t]{2}{*}{ Fase } & \multirow{2}{*}{$\begin{array}{l}\text { Skor } \\
\text { maks. }\end{array}$} & \multicolumn{2}{|c|}{ Pertemuan I } & \multicolumn{2}{|c|}{$\begin{array}{l}\text { Pertemuan } \\
\text { II }\end{array}$} & \multicolumn{2}{|c|}{ Rata-rata } \\
\hline & & & skor & $\%$ & skor & $\%$ & skor & $\%$ \\
\hline 1 & $\begin{array}{l}\text { Orientasi siswa pada } \\
\text { masalah }\end{array}$ & 20 & 15,5 & 77,5 & 17,4 & 87 & 16,45 & 82,25 \\
\hline 2 & $\begin{array}{l}\text { Mengorganisasi siswa } \\
\text { untuk belajar }\end{array}$ & 10 & 7.3 & 73 & 8.5 & 85 & 7.9 & 79 \\
\hline 3 & $\begin{array}{l}\text { Membimbing peng- } \\
\text { alaman } \\
\text { individual/ } \\
\text { kelompok }\end{array}$ & 5 & 3.7 & 74 & 4.2 & 84 & 3.95 & 79 \\
\hline 4 & $\begin{array}{l}\text { Mengembangkan dan } \\
\text { menyajikan hasil } \\
\text { karya }\end{array}$ & 10 & 6,7 & 67 & 8,4 & 84 & 7.55 & 75.5 \\
\hline \multirow[t]{2}{*}{5} & $\begin{array}{l}\text { Menganalisis dan } \\
\text { mengevaluasi proses } \\
\text { pemecahan masalah }\end{array}$ & 10 & 6,6 & 66 & 8,7 & 87 & 7,65 & 76,5 \\
\hline & Rata-rata & 11 & 7,96 & 71,5 & 9,44 & 85,4 & 8,7 & 78,45 \\
\hline
\end{tabular}

Dari tabel 13 dapat diketahui bahwa pelaksanaan PBM di kelas eksperimen ratarata memperoleh skor $7,96(71,5 \%)$ pada pertemuan pertama dan $9,44(85,4 \%)$ pada pertemuan kedua. Sehingga rata-rata pelaksanaan PBM keseluruhannya mencapai skor rata-rata $8,7(78,45 \%)$. Apabila dicermati maka dari lima fase pelaksanaan PBM diketahui bahwa fase empat dan lima adalah fase yang paling rendah skornya dibandingkan dengan fase-fase lainnya. Siswa selama ini jarang sekali atau bahkan belum pernah mendapatkan model pembelajaran seperti PBM sehingga nampak merasa kesulitan dalam mengembangkan pemikiran untuk menyajikan hasil karya berupa laporan. Siswa lebih sering memperoleh materi pembelajaran secara langsung dari guru tanpa harus bekerja dan berpikir keras untuk membuat laporan, siswa juga nampak merasa kesulitan dalam hal menganalisis dan mengevaluasi proses pemecahan masalah. Siswa juga belum terbiasa menjalani presentasi hasil karya di depan kelas sehingga saat penyampaian materi terlihat gugup. Pada saat penyampaian materi siswa harus fokus terhadap materi yang disampaikan dan sekaligus harus memperhatikan kelompok siswa lain yang memperhatikan penyajiannya. Kesulitan lain pada fase lima ini adalah saat penyaji harus menjawab pertanyaan dari kelompok siswa yang lain, siswa penyaji cukup lama untuk dapat menjawab pertanyaan yang disampaikan sehingga menimbulkan sedikit kegaduhan dan penurunan konsentrasi kelompok siswa peserta dan beralihnya perhatian siswa ke hal-hal lain.

\section{SIMPULAN}

Berdasarkan rumusan masalah, hasil penelitian dan analisis data maka dapat dikemukakan simpulan dari hasil penelitian ini, yaitu: 1) ada perbedaan sikap sikap siswa pada lingkungan di kelas eksperimen antara sebelum (pretest) dan sesudah perlakuan (posttest); 2) ada perbedaan sikap siswa pada lingkungan di kelas kontrol antara pretest dan posttest; 3) ada perbedaan sikap siswa pada lingkungan antara kelas eksperimen dan kelas kontrol; 4) ada perbedaan sikap siswa pada lingkungan antara siswa kelompok atas dan kelompok bawah di kelas eksperimen.

Adapun saran dari hasil penelitian ini adalah: 1) Untuk lebih mengaktifkan siswa 
dalam pembelajaran sebaiknya model pembelajaran berbasis masalah (problem based learning) lebih diintensifkan lagi sehingga siswa terlatih untuk menghadapi dan berusaha menyelesaikan masalah yang dekat dengan kehidupannya; 2) Diperlukan penelitian lanjutan tentang prilaku siswa pada lingkungan sehingga mampu menciptakan siswa tidak hanya bersikap baik pada lingkungan tapi juga mampu berprilaku baik pada lingkungan terutama lingkungan yang terdekat dengan dirinya dari hal-hal yang kecil dan memulainya dari diri sendiri.

\section{DAFTAR PUSTAKA}

Amir, M.T. (2013).Inovasi pendidikan melalui problem based learning: bagaimana Pendidik memberdayakan pemelajar di era pengetahuan..Jakarta: Kencana.

Gunawan, M.A. (2013). Statistik untuk penelitianpendidikan, Yogyakarta: Parama Publishing.

http:/ /industri.bisnis.com/read/20160210 /257/517725/pengurangan-sampahplastik-ditargetkan-19-juta-ton

http:/ / madina.go.id/10-januari-selamathari-sejuta-pohon-sedunia/

http:/ / www.antaranews.com/ berita/5509 14/mpr-dukung-jam-bumi:

Juliawan, Didik (2012), Pengaruh model pembelajaran berbasis masalah terhadap pemahaman konsep dan keterampilan proses sains siswa kelas XI IPA SMA Negeri 2 Kuta Tahun Pelajaran 2011/2012,Jurnal Undhiksa, Diakses dari http://pasca.undiksha.ac.id/ejournal/index.php/jurnal_ipa/article/d ownload/400/192.

Kresnawati, Novia, (2013), Korelasi Kualitas Pembelajaran Geografi dan Hasil Belajarterhadap Sikap Peduli Lingkungan Siswa Kelas XII IPSSMAN 1 Ponorogo, Jurnal Pendidikan Humaniora UM, 1(3), hal. 298-303. Diakses dari http://journal.um.ac.id/index.php/jph/ article/download/4139/787.
Khuroidah, A. Dkk. (2013), Peningkatan kemampuan memecahkan masalah dan hasil belajar geografi melalui model pembelajaran problem based learning, Jurnal UM, hal.1-11. Diakses dari http://jurnal-online. um.ac.id data/ artikel/artikel695480FE32D9CF1ECBE37 F411B095213.pdf.

Martanti, H.B. (2009), Kajian etika Islam tentang lingkungan hidup (Tinjauan filosofis), (online), Diakses dari http:/ / digilib.uinsuka.ac.id/6926/1/BA B\% 20I\%20DAN\%20II.pdf.

Muhaimin, (2014), Pengembangan Model problem based learning dalam ecopedagogy untuk peningkatan kompetensi ekologis mata pelajaran IPS (Studi pengembangan model pembelajaran pada siswa SMP Negeri di Kabupaten Bangkalan Jawa Timur), Disertasi, SPs, UPI.

Muryanto, Heri (2012), Hubungan Pendidikan Lingkungan dan Sikap Siswa Terhadap Upaya Pelestarian Lingkungan di SMP Getasan Kabupaten Semarang,Tesis: Program Pascasarjana Universitas Sebelas Maret Surakarta. Onlinetersedia: http:/ / pasca.uns.ac.id/ ?p=2432

Putera, Semara, I.B.N. (2012), Implementasi problem based learning (PBL) terhadap hasil belajar biologi SMA ditinjau dari intelligence quotien ( IQ), Jurnal Undikhsa, Diakses dari: http:/ / pasca.undiksha.ac.id/e-journal/ index.php/jurnal_ipa/article

Sudjana, N. (1989). Penilaian hasil proses belajarmengajar. Bandung: Remaja Rosdakarya.

Wantania,Carla Lucia, (tanpa tahun), Hubungan antara Pendidikan Lingkungan dengan Sikap Siswa SLTP terhadap Pelestarian Lingkungan (Survei tentang Pendidikan Lingkungan pada siswa SLTP di Jakarta), Tesis, UI, tersedia online:

http:/ /lib.ui.ac.id/opac/themes/libri2/ detail. jsp?id=78196\&lokasi=lokal

Yani, A. (2013). Mindset kurikulum 2013. Bandung: Alfabeta. 